\title{
Variation Among Isolates of Colletotrichum dematium var. truncata from Soybean and Three Colletotrichum spp. to Benomyl ${ }^{1,2}$
}

\author{
A. Rodriguez-Marcano and J. B. Sinclair ${ }^{3}$
}

\begin{abstract}
Three isolates of the fungal pathogen Colletotrichum dematium var. truncata were obtained from soybean (Glycine max) during the 1975 growing season in central and southern Illinois and labeled Cd-1, Cd-2 and Cd-3. The three isolates produced curved conidia measuring between 17.8 to $23.3 \mu$ long and 3.2 to $5.1 \mu$ wide. Growth rate and spore production were variable among the three isolates with $\mathrm{Cd}-3$ producing the most spores per $\mathrm{cm}^{2}$ of colony growth and Cd-2 producing the largest colony growth at $25^{\circ} \mathrm{C}$. Isolate Cd-1, found to be tolerant to benomyl in vitro, showed a uniform radial-growth pattern on potato-dextrose agar amended with 1 to $350 \mu \mathrm{g} / \mathrm{ml} \mathrm{commercial}$ benomyl, while isolates $\mathrm{Cd}-2$ and $\mathrm{Cd}-3$ showed a bimodal-type growth curve. Colletotrichum glycine and Colletotrichum musae were sensitive to benomyl.
\end{abstract}

\section{INTRODUCTION}

Several seedborne fungal pathogens have been described in soybean (Glycine max (L.) Merr.) (11). Among them is Colletotrichum dematium (Pers. ex Fr.) var. truncata (Schw.) Andrus and W. D. Moore, causal agent of soybean anthracnose $(5,6,13)$. Anthracnose diseases have been recorded in all major soybean growing areas of the world (10).

Susceptibility of soybean to Colletotrichum spp., has been recorded at all stages of plant growth. In advanced stages the disease appears primarily on stems and pods as indefinite brown areas $(6,12,13)$. When diseased seeds are planted, numerous seedlings are killed before or after emergence. Dark brown sunken cankers often develop on the cotyledons of emerging seedlings $(6,8)$. The most destructive phase of the disease occurs in maturing plants, particularly during rainy periods. Young: soybean pods also may be attacked and killed. Mycelium of the anthracnose fungus may completely fill the pod cavity resulting in dark brown, shriveled and moldy seed $(5,12)$.

Debris-borne and seedborne inoculum may cause pre- and postemergence damping-off of seedlings $(6,11)$, or mycelium may become estab-

'Manuscript submitted to Editorial Board August 8, 1980.

${ }^{2}$ This report covers work conducted cooperatively between the Colleges of Agriculture of the Universities of Illinois, Urbana-Champaign and of Puerto Rico, Mayagüez, through the International Soybean Program (INTSOY), and is a portion of the senior author's M.Sc. Thesis at the University of Illinois. It was supported in part by the Illinois Agricultural Experiment Station.

${ }^{3}$ Assistant Phytopathologist, University of Puerto Rico, Mayagüez Campus, Agricultural Experimental Station, Rio Piedras, P.R. and Professor, Department of Plant Pathology, University of Illinois, Urbana 61801 , respectively. 
lished in the seeds without producing symptom of disease. Virulence among $C$. dematium var. truncata isolates has been studied but the existence of races of the pathogen has not been established $(5,13)$.

\section{MATERIALS AND METHODS \\ MORPHOLOGICAL CHARACTERS}

Twenty isolates of the curved-spored $C$. dematium var. truncata were obtained from soybeans in different localities in central and southern Illinois to determine the degree of variation among the isolates. The isolates were placed in three groups based on morphological and cultural characters. Single spore subisolates from each group were identified as Cd-1, Cd-2 or Cd-3.

Isolate $\mathrm{Cd}-1$ was obtained from a Wells soybean seed harvested from a benomyl-sprayed plot on South Farm, University of Illinois, UrbanaChampaign. Isolate Cd-2 was obtained from a dried stem of an Amsoy soybean plant harvested in Jefferson County, Illinois. Isolate Cd-3 was obtained from an Amsoy 71 pod collected from the University of Illinois Agronomy South Farm. All isolates were collected in the 1975 growing season.

The three isolates were cultured on Gibco (Gibco Diagnostic, Madison, Wisconsin 53713$)^{4}$ potato-dextrose agar (PDA) and kept at $25^{\circ} \mathrm{C}$. Colony morphology, cultural growth habits on PDA, conidia size and shape of the isolates were recorded. The three isolates were sent to the Commonwealth Mycological Institute, Kew, Surrey, England, where they confirmed to be within the $C$. dematium Grove group.

\section{EFFECT OF TEMPERATURE ON MYCELIA GROWTH AND CONIDIA PRODUCTION}

Monoconidial cultures of the three isolates were tested at different temperatures. Six culture plates containing approximately $20 \mathrm{ml}$ of PDA were seeded separately with a 5-mm PDA dises of each of the three isolates. The discs were cut with a cork borer from advancing margins of colonies. Culture plates containing the inoculum were incubated for 7 days at $5,15,20,25,30$ or $35^{\circ} \mathrm{C}$. Colony diameters were recorded at the end of each incubation period.

A spore count was made for each isolate at each incubation temperatures. A spore suspension was prepared by scraping the surface of the PDA colony before flooding with approximately $15 \mathrm{~cm}^{3}$ of sterile distilled

\footnotetext{
${ }^{4}$ Trade names in this publication are used only to provide specific information. Mention of a trade name does not constitute a warranty of equipment or materials by the Agricultural Experiment Station of the University of Puerto Rico, nor is this mention a statement of preference over other equipment or materials.
} 
water. Spores were counted with a hemacytometer. The number of spores per area of colony growth was recorded.

IN VITRO ACTIVITY OF BENOMYL AGAINST THREE ISOLATES OF C. DEMATIUM VAR. TRUNCATA, C. GLYCINE, AND C. MUSAE

Benomyl (methyl 1-(butylcarbamoyl) -2-benzimidazolecarbamate (E. I. du Pont's Benlate 50 WP) concentrations were evaluated in vitro against three isolates of $C$. dematium var. truncata and single isolates of C. glycine (Hori) Lehman and Wolf from soybean and C. musae (Berke. \& Curt.) Arx from banana (the latter two highly sensitive to benomyl and obtained from C. A. Shillingford, Urbana). Sensitivity of these fungi to a series of 1 to $350 \mu \mathrm{g} / \mathrm{ml}$ solutions of benomyl was determined by adding the appropriate amounts of the commercial fungicide to either autoclaved $\left(121^{\circ} \mathrm{C} / 15 \mathrm{~min}\right) \mathrm{PDA}$ cooled to about $50^{\circ} \mathrm{C}$ or to the powdered PDA in a water mixture which was then autoclaved at $121^{\circ} \mathrm{C}$ for $15 \mathrm{~min}$. Potatodextrose agar without fungicide served as a control. Twenty ml of nonamended (control) or amended PDA for each treatment were poured into each of six 9-cm culture plates. After the agar had solidified, a 6-mm agar plug was cut from 8- to 10-day-old cultures with a sterile cork borer and placed in the center of the test plate. All plates were randomized in an incubator programmed for constant light and $26^{\circ} \mathrm{C}$. Mean colony diameter was recorded after 8 days. The FLSD Test for significance was applied to the data (14).

\section{RESULTS}

\section{MORPHOLOGICAL CHARACTERS}

\section{Isolate Cd-1}

Colonies on PDA were dark-gray with sparse aerial mycelium, extensive production of stromatic acervuli on the surface and within the substrate and with a tendency to form sclerotial aggregates of dark mycelium (fig. 1). Single conidia appeared hyaline but were pinkish when in masses. The conidia were falcate and truncate, uninucleate with oil droplets in the cytoplasm (fig. 2). Conidia formation always was accompanied by dark colored, straight setae and production in the culture medium was more abundant at $35^{\circ} \mathrm{C}$ than at 25 and $30^{\circ} \mathrm{C}$ after 5 days. Fungal growth covered the 9 -cm culture plates within 8 to 10 days at $25^{\circ}$ $\mathrm{C}$ and 6 to 8 days at $30^{\circ} \mathrm{C}$. Isolate $\mathrm{Cd}-1$ had the smallest spore size of the three isolates (table 1).

\section{Isolate $\mathrm{Cd}-2$}

Colonies on PDA initially were olivaceous and turned dark gray after 8 days (fig. 1). The fungus produced soft stromatic acervuli with abundant 
production of whitish masses of conidia at $30^{\circ} \mathrm{C}$. Sparse mycelia were flattened to the substrate with black stroma produced after 8 to 10 days. Conidia were hyaline, falcate and uninucleate (fig. 2), and produced in the presence or absence of short flexible setae. The fungus incubated in constant light at 25 or $30^{\circ} \mathrm{C}$ covered the 9 -cm culture plates within 8 to 9 days and 6 to 7 days, respectively.

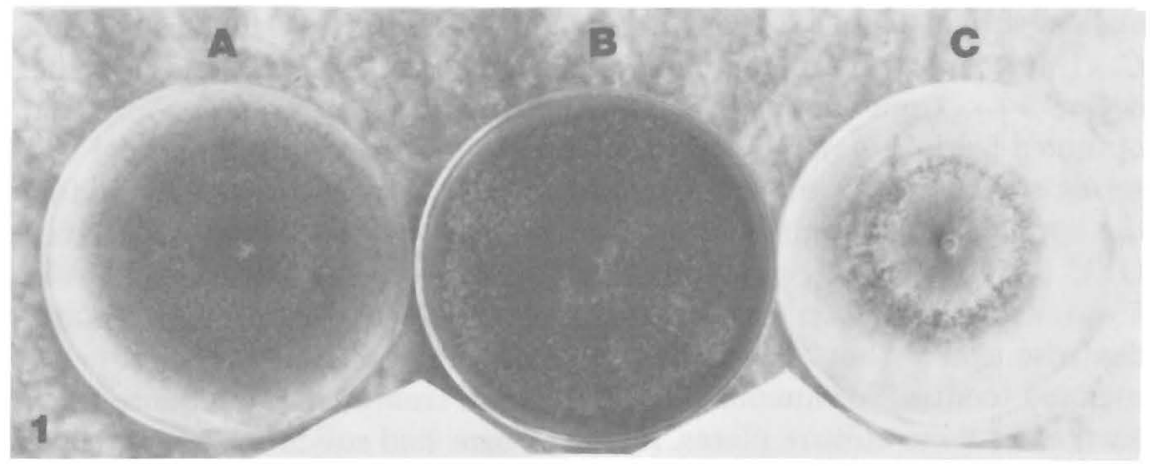

FIG. 1.-Colony morphology of three isolates of Colletotrichum sp. (within the Colletotrichum dematium (Pers. ex. Fr.) Grove group from soybean (Glycine max) (A. Cd-1, B. Cd-2, and C. Cd-3).

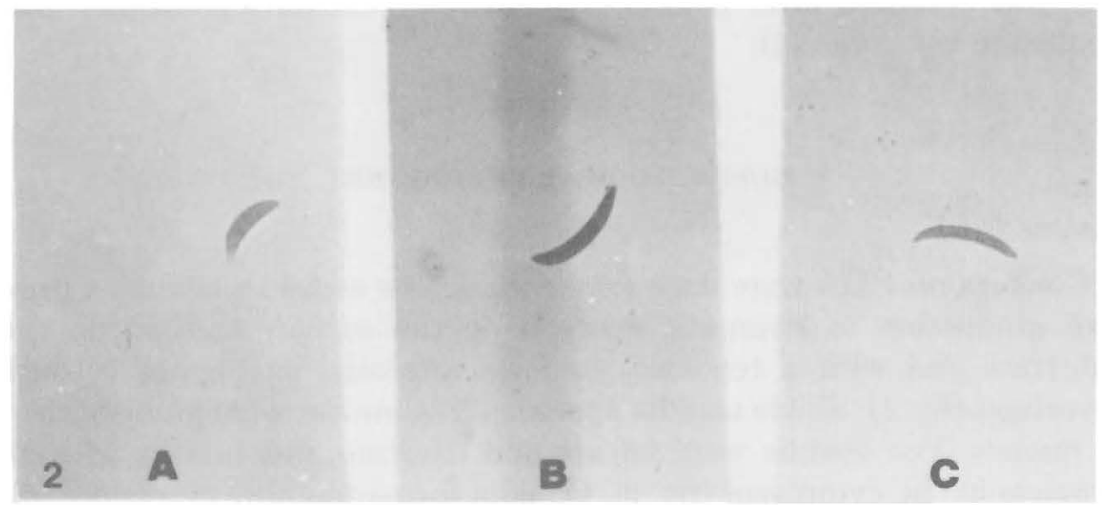

FIG. 2.-Conidia of three isolates within the Colletotrichum dematium (Pers. ex. Fr.) Grove group (A. Cd-1, B. Cd-2, and C. Cd-3) $(\times 300)$.

\section{Isolate Cd-3}

Colonies on PDA were dark-gray with abundant aerial mycelium and a dark-brown stroma produced under the substrate. The colony showed zonation with an irregular margin immersed in the substrate. Conidia were large (table 1), symetrically falcate, nonseptate and uninucleate (fig. 2 ). Whitish conidia were produced with or without small flexible setae. 
The fungus grew slowly, covering culture plates within 13 to 15 days at $25^{\circ} \mathrm{C}$ and 10 to 12 days at $30^{\circ} \mathrm{C}$ in constant light.

EFFECT OF TEMPERATURE ON MYCELIA GROWTH AND CONIDIA PRODUCTION

The optimum temperature for mycelial growth of the three isolates was between $25^{\circ} \mathrm{C}$ and $30^{\circ} \mathrm{C}$ (fig. 3). Isolate $\mathrm{Cd}-2$ showed the largest colony growth at $25^{\circ} \mathrm{C}$. Isolates $\mathrm{Cd}-1$ and $\mathrm{Cd}-3$ produced optimum growth at $30^{\circ} \mathrm{C}$, but isolate $\mathrm{Cd}-3$ grew slowly at all temperatures.

Spore production of the different isolates varied considerably (fig. 4). Isolate Cd-3 produced the largest number of spores per $\mathrm{cm}^{2}$ of growth between 20 and $30^{\circ} \mathrm{C}$, isolate $\mathrm{Cd}-2$ at $25^{\circ} \mathrm{C}$, and isolate $\mathrm{Cd}-1$ at $35^{\circ} \mathrm{C}$.

TABLE 1.-Size of conidia of three isolates of Colletotrichum dematium var. truncata from soybeans (Glycine max)

\begin{tabular}{clccc}
\hline \multirow{2}{*}{ Isolate } & \multirow{2}{*}{ Source } & \multicolumn{3}{c}{ Measurements of conidia $(\mu)^{\prime}$} \\
\cline { 3 - 5 } & & Length & Width & Curvature \\
\hline Cd-1 & Seed of cv. Wells & $17.75-23.65$ & $3.15-5.62$ & 6.12 \\
Cd-2 & Seed of cv. Amsoy 71 & $21.25-27.75$ & $3.40-4.75$ & 6.75 \\
Cd-3 & Seed of cv. Amsoy 71 & $22.50-28.30$ & $3.39-5.10$ & 5.93 \\
\hline
\end{tabular}

'Range of measurements based on 75 conidia per each isolate.

IN VITRO ACTIVITY OF BENOMYL AGAINST THREE ISOLATES OF C. DEMATIUM VAR. TRUNCATA, C. GLYCINE AND C. MUSAE

There were differences in sensitivity to benomyl among the three isolates of $C$. demantium var. truncata, C. glycine and C. musae (fig. 5). Radial mycelial growth always was less than the control for all concentrations of benomyl. There was no significant reduction in radial growth with increase in fungicide concentration for any isolate except for isolate Cd-3 which showed a bimodal curve on PDA containing either autoclaved or nonautoclaved benomyl and for isolate Cd-2 which showed no growth at $125 \mu \mathrm{g} / \mathrm{ml}$ of autoclaved benomyl. There were significant differences in colony growth between the isolates $\mathrm{Cd}-1, \mathrm{Cd}-2$ and $\mathrm{Cd}-3$ at all concentrations FLSD $(\mathrm{P}=0.05)=1.45$; except at $125 \mu \mathrm{g} / \mathrm{ml}$ where $\mathrm{Cd}-2$ and $\mathrm{Cd}-3$ did not show significant differences in either autoclaved and nonautoclaved benomyl. Isolate Cd-1 maintained almost constant growth at all concentrations after 10 days, demonstrating a relative insensitivity to the compound. Colletotrichum glycine and C. musae were more sensitive to benomyl than the three isolates of $C$. dematium var. truncata. All fungal isolates produced similar response curves to both autoclaved and nonautoclaved benomyl, except for isolates $\mathrm{Cd}-1$ and $\mathrm{Cd}-2$, where radial growth was lower in the autoclaved benomyl than the nonautoclaved benomyl. 


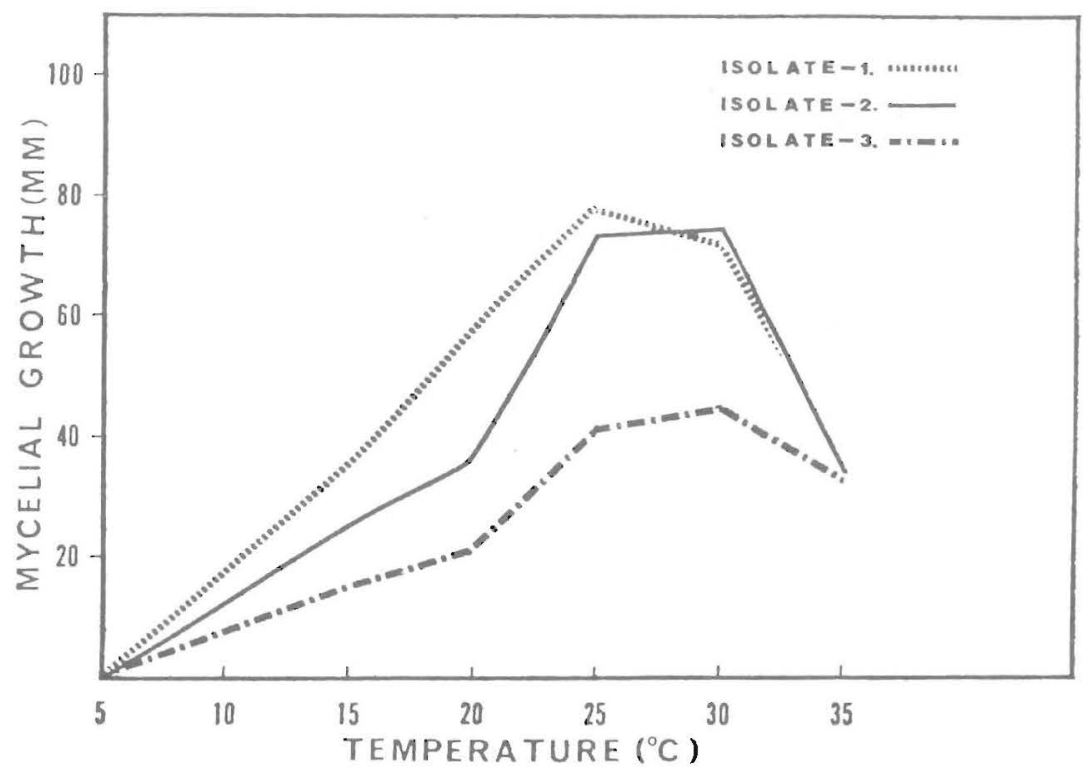

FIG. 3.-Effect of temperature on mycelial growth of three isolates of Colletotrichum dematium var. truncata from soybean (Glycine $\max )$. Isolate $1=\mathrm{Cd}-1$; Isolate $2=\mathrm{Cd}-2$; Isolate $3=\mathrm{Cd}-3$.

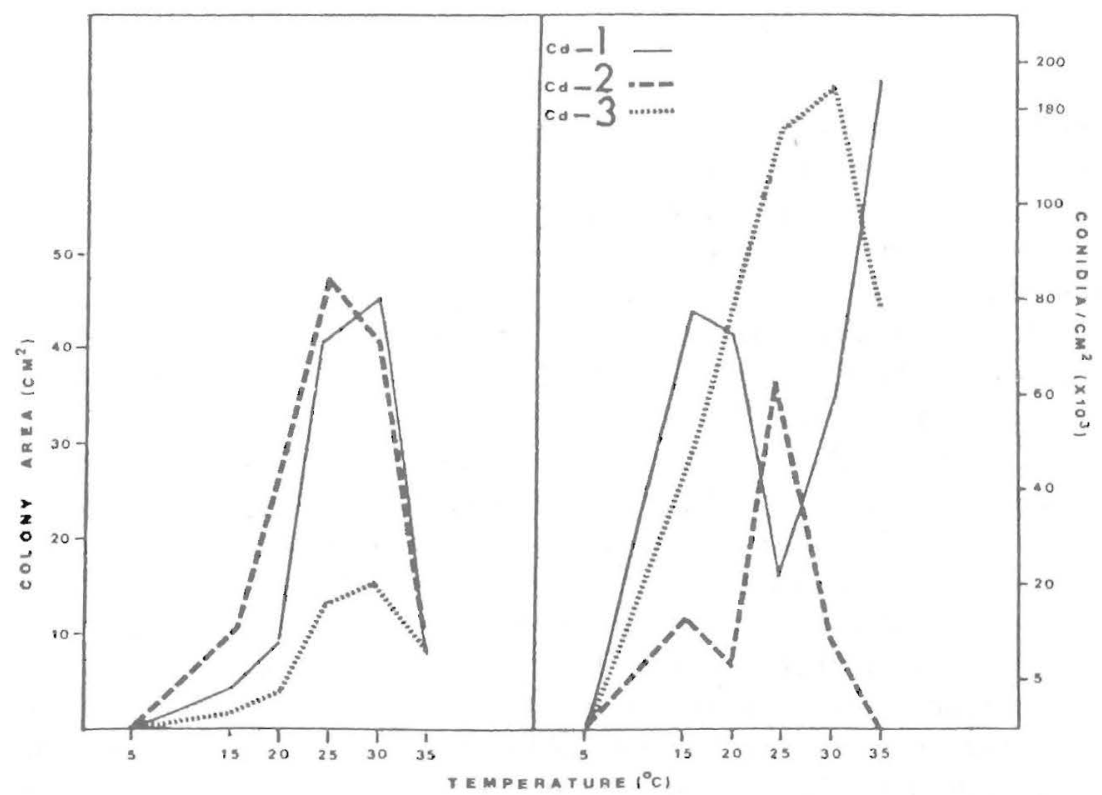

FIG. 4.-Relationship of conidia production and colony area to incubation temperature in three isolates of Colletotrichum dematium var. truncatum (Cd-1, Cd-2 and Cd-3). 


\section{DISCUSSION}

Three distinct isolates of $C$. dematium var. truncata were found by comparing single-spore cultures of the collection. All three isolates produced curved conidia on PDA, similar to those described by previous workers $(5,13)$. Further studies are necessary, particularly with respect to their host range and its virulence, to determine whether the strains

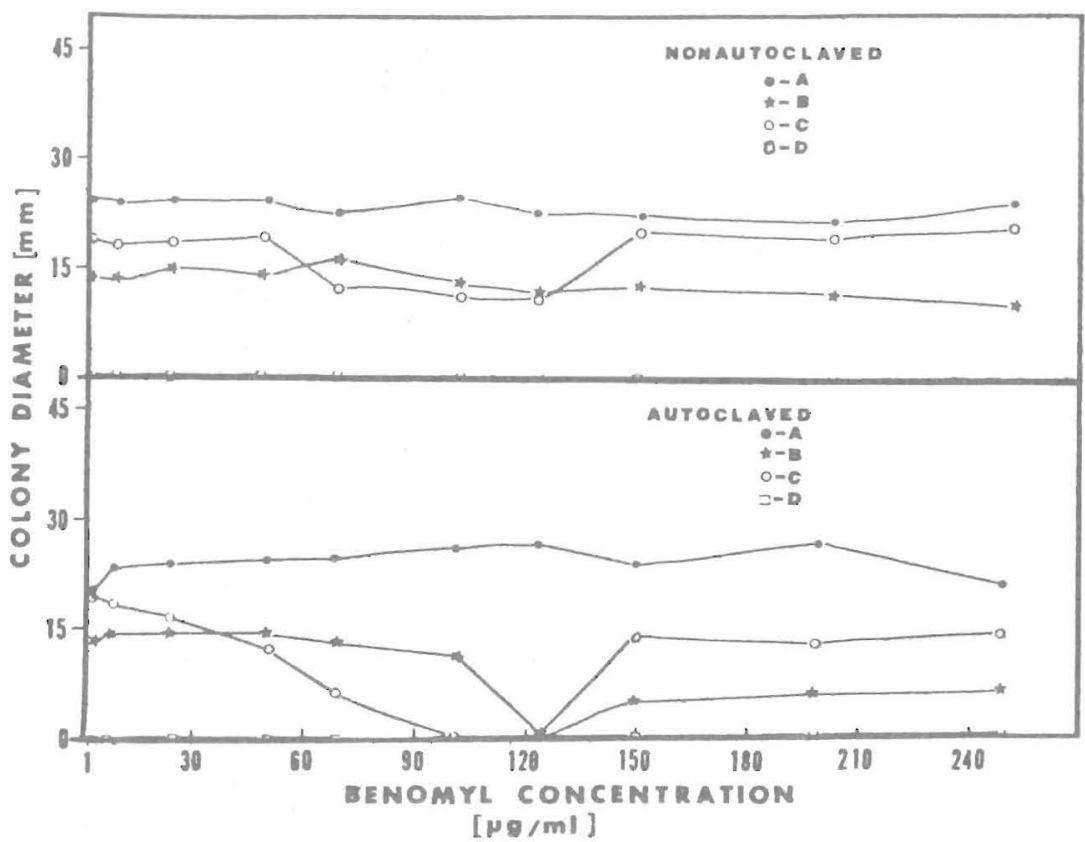

FiG. 5.-Benomyl sensitivity of three isolates of Colletrotrichum dematium var. truncatum, Colletotrichum glycine (isolated from soybean (Glycine max)) and Colletotrichum musae (isoalted from banana (Musa spp.)). There were no significant differences in mean colony diameters between autoclaved and nonautoclaved treatments. There were significant differences between all other treatments. FLSD $(P=0.05)=1.45$. Isolate $\mathrm{A}=\mathrm{Cd}-1$; Isolate $\mathrm{B}=\mathrm{Cd}-2$; Isolate $\mathrm{C}=\mathrm{Cd}-3$; Isolate $\mathrm{D}=C$. glycine and $C$. musae with the same response curve.

represent true races of the pathogen. They should be compared with similar Colletotrichum sp. isolates of other research workers $(5,12)$.

In recent years, the practice of spraying with fungicides, particularly benomyl, for control of fungal disease complexes has been increasing (3, 9). With the widespread use of benomyl in soybean as in other crops (1, 2 ), benomyl-tolerant strains of soybean fungal pathogens may eventually be found. Isolate Cd-1, which came from a benomyl sprayed plant, was tolerant to benomyl, showing similar radial growth at all concentrations used. 
Colletotrichum glycine and C. musae were shown to be sensitive to benomyl, which reduced mycelial growth in an amended medium at concentrations as low as $1 \mu \mathrm{g} / \mathrm{ml}$. The three isolates of $C$. dematium var. truncata showed differences in sensitivity to benomyl. A biomodal curve resulted when radial growth was plotted against dosage of benomyl for isolates $\mathrm{Cd}-2$ and $\mathrm{Cd}-3$. A similar response curve was detected by previous workers $(4,7)$ working with dimethyldithiocarbamate and tetramethylthiuram raising the possibility of chemical-fungal membrane reaction in the medium and the rate of disassociation of the toxic chemicals in the medium.

\section{RESUMEN}

En 1975 tres subcultivos de Colletotrichum dematium var. truncata se obtuvieron de sojas sembradas en las regiones central y meridional de Illinois. Estas se designaron Cd-1, Cd-2 y Cd-3. Los tres subcultivos produjeron conidios curvados que medían entre 17.8 y $23.3 \mu$ de largo y de 3.2 a 5.1 de ancho. La tasa de crecimiento y la producción de esporas de los tres variaron: el Cd-3 fue el que más esporas produjo por $\mathrm{cm}^{2}$ y el Cd-2 el que produjo la colonia más grande a $25^{\circ} \mathrm{C}$. El Cd-1 fue tolerante al benomyl in vitro y presentó un crecimiento radial uniforme en agar de papa y dextrosa modificado con 1 a $350 \mu \mathrm{g} / \mathrm{ml}$ de benomyl comercial. Los subcultivos Cd-2 y Cd-3 presentaron una curva bimodal de crecimiento. Colletotrichum glycine y $C$. musae fueron sensibles al benomyl.

\section{LITERATURE CITED}

1. Bollen, G. J. and G. Scholten, 1971. Acquired resistance to benomyl and some other systemic fungicides in a strain of Botrytis cinerea in cyclamen, Neth. J. Plant Pathol. 77: 83-90.

2. Chamberlain, D. W. and L. E. Gray, 1974. Germination, seed treatment and microorganisms in soybean seed produced in Illinois, Plant Dis. Rep. 58: 50-54.

3. Dekker, J., 1969. Acquired resistance to fungicides, World Rev. Pest Control 8: 79-85.

4. Diamond, A. E., J. G. Horsfall, J. W. Heuberger and E. M. Stoddard, 1941. Conn. Agric. Exp. Stn. Bull. 451: 635-637.

5. Lin, Y. S. and C. W. Lung, 1966. Seed-borne diseases of soybean in Taiwan, Bull. Plant Pro. 8: 305-318.

6. Ling, L., 1940. Seedling stem blight of soybean caused by Glomerella glycine, Phytopathology 30: $345-347$.

7. Martin, R., 1964. The scientific principles of crop protection, St. Martin Press, New York. $375 \mathrm{pp}$.

8. Mengistu, A. and J. B. Sinclair, 1979. Seedborne microorganisms of Ethiopian-grown soybean and chickpea seeds, Plant Dis. Rep. 63: 616-619.

9. Prasartsee, C., F. D. Tenne, M. B. Ilyas, M. A. Ellis and J. B. Sinclair, 1975. Reduction of internally seedborne Diaporthe phaseolorum var. sojae by fungicide sprays, Plant Dis. Rep. 59: 20-23.

10. Sinclair, J. B. and O. D. Dhingra, 1975. An annotated bibliography of soybean diseases 1882-1975, INTSOY Pub. No. 9, Univ. Ill. Press, Urbana. 275 pp. 
11. _- and M. C. Shurtleff, 1975. Compendium of soybean diseases, Am. Phytopathol. Soc., St. Paul, Minnesota. 69 pp.

12. Tiffany, L. H., 1951. Delayed sporulation of Colletotrichum spp. on soybean. Phytopathology 41: 975-985.

13. ——, 1954. Species of Colletotrichum from legumes. Mycologia 46: 52-75.

14. Woolf, C. M., 1968. Principles of Biometry, D. Van Nostrand Company, Inc. 359 p. 